\title{
Agricultural Drainage Ditches Mitigate Phosphorus Loads as a Function of Hydrological Variability
}

\author{
R. Kröger* and M. M. Holland University of Mississippi Field Station and Center for Water and Wetland Resources \\ M. T. Moore and C. M. Cooper USDA-ARS
}

Phosphorus (P) loading from nonpoint sources, such as agricultural landscapes, contributes to downstream aquatic ecosystem degradation. Specifically, within the Mississippi watershed, enriched runoff contributions have far-reaching consequences for coastal water eutrophication and Gulf of Mexico hypoxia. Through storm events, the $\mathrm{P}$ mitigation capacity of agricultural drainage ditches under no-till cotton was determined for natural and variable rainfall conditions in north Mississippi. Over $2 \mathrm{yr}$, two experimental ditches were sampled monthly for total inorganic $\mathrm{P}$ concentrations in baseflow and on an event-driven basis for stormflows. Phosphorus concentrations, Manning's equations with a range of roughness coefficients for changes in vegetative densities within the ditches, and discharge volumes from Natural Resources Conservation Service dimensionless hydrographs combined to determine ranges in maximum and outflow storm $\mathrm{P}$ loads from the farms. Baseflow regressions and percentage reductions with $\mathrm{P}$ concentrations illustrated that the ditches alternated between being a sink and source for dissolved inorganic $\mathrm{P}$ and particulate $\mathrm{P}$ concentrations throughout the year. Storm event loads resulted in $5.5 \%$ of the annual applied fertilizer to be transported into the drainage ditches. The ditches annually reduced $43.92 \pm 3.12 \%$ of the maximum inorganic effluent $\mathrm{P}$ load before receiving waters. Agricultural drainage ditches exhibited a fair potential for $\mathrm{P}$ mitigation and thus warrant future work on controlled drainage to improve mitigation capacity.

Copyright $\odot 2008$ by the American Society of Agronomy, Crop Science Society of America, and Soil Science Society of America. All rights reserved. No part of this periodical may be reproduced or transmitted in any form or by any means, electronic or mechanical, including photocopying, recording, or any information storage and retrieval system, without permission in writing from the publisher.

Published in J. Environ. Qual. 37:107-113 (2008).

doi:10.2134/jeq2006.0505

Received 20 Nov. 2006.

*Corresponding author (kroger@olemiss.edu).

(c) ASA, CSSA, SSSA

677 S. Segoe Rd., Madison, WI 53711 USA
$\mathrm{E}^{\mathrm{N}}$ NVIRONMENTAL issues surrounding phosphorus (P) contamination are primarily linked to its impact on surface water eutrophication. A better understanding of $\mathrm{P}$ loading from nonpoint sources (e.g., agriculture) (Jolankai and Rast, 1999) and eventually into coastal waters (e.g., the Gulf of Mexico) is of increasing interest and importance because of the numerous ecological impacts on freshwater and marine biota (House et al., 1995; Rabalais et al., 1996; Turner and Rabalais, 2003). In many instances, the genesis of nonpoint source P loads stems from drainage of agricultural lands.

Agricultural land is artificially drained by surface drainage ditches, subterranean tiles, or a combination of both (Fausey et al., 1995; Kovacic et al., 2000). There are two contrasting hypotheses for drainage ditch function: (i) Artificial drainage enhances transport of $\mathrm{P}$ rich runoff and thus loses the opportunity for retention, transformation, and mitigation, and (ii) conversely, drainage may reduce the spatial extent of waterlogging, which increases soil redox, promoting phosphate adsorption and co-precipitation with $\mathrm{Fe}^{3+}$ complexes (Dils and Heathwaite, 1999; Heathwaite and Dils, 2000). Functionally, from a farmer's standpoint, agricultural drainage ditches lower water tables, reduce the incidence of pooling and flooding of flood-intolerant croplands, and improve soil aeration (Dils and Heathwaite, 1999). Agricultural drainage ditches are important routes of preferential flow in agricultural systems (Haygarth et al., 2000), providing a rapid, more direct route for P-laden drainage waters to reach receiving waters. Drainage ditches are truly forgotten links between agricultural farms and receiving waters (Moore et al., 2000), and no research has investigated using these agricultural landscape features for P mitigation associated with high-intensity storm events.

Surface runoff is a major avenue for P loss from agricultural areas (Fraser et al., 1999). The loss of P in surface runoff occurs in the particulate and dissolved forms (Sharpley et al., 1994). Particulate P loss from farm soils is a complex problem determined by the nature of rainfall intensity, duration, soil type, and management factors. Dissolved $\mathrm{P}$ travels in runoff as rainfall interacts with a thin layer of surface soil $(1-2.5 \mathrm{~cm})$ before leaving the field. Certain management factors, such as no-till, lead to soil capping under rain impact, enhancing surface or overland runoff (Fraser et al., 1999). Sharpley et al. (1996) reported that agricultural fields may supply $\mathrm{P}$ concentrations in excess of critical levels, although they suggest that a reduction might occur

R. Kröger and M.M. Holland, University of Mississippi Field Station and Center for Water and Wetland Resources, 15 CR 2078, Abbeville MS 38601. M.T. Moore and C.M. Cooper, USDA-ARS, National Sedimentation Lab., Oxford, MS 38655.

Abbreviations: DIP, dissolved inorganic phosphorus; NRCS, Natural Resources Conservation Service; PP, particulate phosphorus; TIP, total inorganic phosphorus. 
during the transport process before entering receiving waters such as lakes.

There is a lack of information concerning how well agricultural landscape features, such as surface drainage ditches, can mitigate P loss from row-crop agriculture. The aim of this paper is to provide an estimative measurement of the mitigation capacity of dissolved inorganic and particulate $\mathrm{P}$ loads within agricultural drainage ditches in the lower Mississippi Alluvial Valley, USA. In this study, we investigated $\mathrm{P}$ load reductions along two surface drainage ditches as influenced by season and rainfall patterns.

\section{Materials and Methods}

The current study consisted of two surface drainage ditches sampled over a 2-yr period from June 2004 to June 2006. The study sites occurred within the Little Tallahatchie Watershed, Lafayette County, Mississippi. The farms had been planted in cotton (Gossypium sp.) since 1995 in a summer-row, winter fallow crop sequence. A common cropping strategy in northern Mississippi to achieve this goal is a summer row-crop (April-September), winter (October-March) fallow sequence. This farming practice has several consequences. High rainfall intensity over winter results in soil saturation and subsequently surface flow and overland runoff (Haygarth et al., 2000). In winter, a lack of cover crops, heavy rains, and sparse vegetation within the drainage ditches result in higher flow velocities, lack of $P$ sedimentation, and an increase in P loads (Wright et al., 2001). Before 1995, the farms were planted with an annually alternating soybean-cotton crop. The two farms had identical farming practices of row cropping, no-till, and split fertilizer applications. Fertilization occurred annually with ammonium nitrate $\left(\mathrm{NH}_{4} \mathrm{NO}_{3}\right)$ and $\mathrm{P}$. An initial application of $112 \mathrm{~kg} \mathrm{ha}^{-1}$ of $\mathrm{NH}_{4} \mathrm{NO}_{3}$ and $56 \mathrm{~kg} \mathrm{ha}^{-1} \mathrm{P}$ occurred in late May and June of 2004 and 2005, respectively. This was followed by a single split application of $56 \mathrm{~kg} \mathrm{ha}^{-1} \mathrm{NH}_{4} \mathrm{NO}_{3}$ when cotton was six nodes in height (approximately early July). The size of Farm 1 was 13.1 ha, and Farm 2 was 13.3 ha. Both farms consisted primarily of fine Chenneby silt loams and sandy loams (Morris, 1981). Drainage ditches were 400 and $460 \mathrm{~m}$ long, respectively, had bank depths of $0.65 \pm 0.02 \mathrm{~m}$ and $0.73 \pm 0.09 \mathrm{~m}$, bankfull widths of $4.67 \pm 0.19 \mathrm{~m}$ and $4.61 \pm 0.56 \mathrm{~m}$, and average width/depth ratios of $7.15 \pm 0.18$ and $6.63 \pm 0.81$, respectively. Drainage of the two farms was exclusively performed by these surface drainage ditches with the only water that had drained from the farms entering the ditch. Drainage ditch systems were installed when the farms were first established (1980s) and when they were last clear scraped in 2000. No herbicide or vegetation-clearing maintenance occurred on either ditch through the duration of the study.

\section{Water Sampling}

Sampling occurred along a stratified longitudinal gradient at seven equidistant sampling points (approximately $50 \mathrm{~m}$ apart) and an outflow site ( $n=8$ per ditch). Water sampling was divided into monthly baseflow samples and storm event samples. Baseflow grab samples were taken monthly from each sampling location within the ditches to determine seasonal, annual, and interannual differences in nutrient concen- trations. All water samples were transported to the lab in an ice chest and stored at $0^{\circ} \mathrm{C}$ until analyzed.

Storm event samples were water samples collected after a rainfall event that generated sufficient runoff to elevate the water levels within the drainage ditch. Storm events generated an increase in water volume, velocity, and surface runoff. The storm water sample was obtained using a $400-\mathrm{mL}$ sampling container attached to a stake in the middle of the ditch, suspended 2 to $3 \mathrm{~cm}$ above the baseflow water level. The storm sample is a conservative nutrient measure of the storm event because it constitutes a bulk water sample of rising, peak, and falling limbs of the storm hydrograph. Storm containers were sampled within 24 to $48 \mathrm{~h}$ after storm events.

\section{Nutrient Analyses}

Phosphorus exists in many forms, such as dissolved or soluble, unreactive, reactive, or biologically active. For convenience these types were grouped into three classes. Dissolved inorganic phosphorus (DIP) represented a soluble, mobile, very biologically available form of P (Murphy and Riley, 1962; House et al., 1995) that includes orthophosphates, organic-P, and polyphosphates. Particulate phosphorus (PP) represented the particulate phosphates and particulate organic $\mathrm{P}$ adsorbed to sediment particles of varying size and is less directly available to algae and macrophytes. Total inorganic phosphorus (TIP) was the sum of DIP and PP (Broberg and Persson, 1988).

Total inorganic $\mathrm{P}$ was determined analytically using the ammonia persulfate digestion procedure (Murphy and Riley, 1962; APHA 1998). The detection limits were 0.001 to $10.0 \mathrm{mg} \mathrm{L}^{-1}$ $P$ for photometric measurements performed at $880 \mathrm{~nm}$ in a 50 $\mathrm{mm}$ tubular flow cell. Dissolved inorganic P was determined following the method of Murphy and Riley (1962) after filtration through a $0.45-\mu \mathrm{m}$ cellulose membrane. The difference between TIP and DIP is the PP fraction. The concentration of orthophosphate pertains to dissolved monomeric inorganic phosphates, $\mathrm{H}_{2} \mathrm{PO}_{4}^{-}, \mathrm{HPO}_{4}^{-}$, and $\mathrm{PO}_{4}^{3-}$, with contributions from organophosphorus compounds and inorganic polyphosphates, which are hydrolyzed to reactive P during the analytical procedure (House et al., 1995). Rainwater was tested for atmospheric P and was found to have below detectable levels.

\section{Stage Height Determination}

A HOBO U20 water level logger recorded real-time water level data at 15-min intervals in each experimental ditch. HOBO U20 loggers detect changes in atmospheric pressure as a correlate of water depth. The water level recorders on both farms were referenced against a standard atmospheric pressure measured by an adjacent water level recorder at a height of 1.5 $\mathrm{m}$ in the woods, less than $50 \mathrm{~m}$ from ditches. Precipitation data were collected at a United States Department of Agriculture weather station located $3.5 \mathrm{~km}$ southeast of farm sites.

Peak discharges for storm events were determined using Manning's equation for discharge:

$\mathrm{Q}=1 / \mathrm{n} \mathrm{AR}^{2 / 3} \mathrm{~S}^{1 / 2}$ 
Table 1. Growing, dormant, and annual hydrological characteristics and mean outflow stormflow concentrations for dissolved orthophosphate and particulate phosphorus. Values are summed and averaged for both farms over 2004 and 2005.

\begin{tabular}{|c|c|c|c|c|c|c|}
\hline \multirow[b]{2}{*}{ Year } & \multirow[b]{2}{*}{ Storm event } & \multirow[b]{2}{*}{ Hydraulic radius } & \multirow[b]{2}{*}{ Max stage } & \multirow[b]{2}{*}{$Q_{p}$} & \multicolumn{2}{|c|}{ Mean outflow $\mathrm{P}$ concentrations } \\
\hline & & & & & DIP† & PP \\
\hline & & $\mathrm{m} \pm \mathrm{SE}$ & $\mathrm{cm} \pm \mathrm{SE}$ & $\mathrm{m}^{3} \mathrm{~s}^{-1}$ & - & 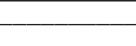 \\
\hline \multirow[t]{3}{*}{ 2004-05 } & growing & $0.21 \pm 0.02$ & $36.3 \pm 5.4$ & $0.0008 \pm 0.0002$ & $0.49 \pm 0.08$ & $2.70 \pm 0.15$ \\
\hline & dormant & $0.30 \pm 0.05$ & $50.9 \pm 11.3$ & $0.011 \pm 0.004$ & $0.27 \pm 0.04$ & $1.75 \pm 0.18$ \\
\hline & annual & $0.26 \pm 0.04$ & $44.9 \pm 6.6$ & $0.006 \pm 0.003$ & $0.35 \pm 0.06$ & $2.10 \pm 0.19$ \\
\hline \multirow[t]{3}{*}{$2005-06$} & growing & $0.29 \pm 0.06$ & $48.9 \pm 10$ & $0.002 \pm 0.001$ & $1.65 \pm 0.17$ & $0.85 \pm 0.12$ \\
\hline & dormant & $0.23 \pm 0.04$ & $39.5 \pm 6.6$ & $0.004 \pm 0.001$ & $1.15 \pm 0.13$ & $1.25 \pm 0.12$ \\
\hline & annual & $0.26 \pm 0.03$ & $43.8 \pm 6$ & $0.003 \pm 0.0008$ & $1.35 \pm 0.16$ & $1.09 \pm 0.14$ \\
\hline
\end{tabular}

† DIP, dissolved inorganic phosphorus; $P$, particulate phosphorus; $Q_{p^{\prime}}$ peak runoff.

where $\mathrm{Q}$ is the flow $\left(\mathrm{m}^{3} \mathrm{~s}^{-1}\right), \mathrm{n}$ is the Manning's roughness coefficient, $A$ is the cross-sectional surface area $\left(\mathrm{m}^{2}\right), \mathrm{R}$ is the hydraulic radius $(\mathrm{m})$, and $\mathrm{S}$ is the slope. Cross-sectional area and slope were measured using a Leica Geosystem Total Station. Water depth and wetted perimeter were determined with $\mathrm{HOBO}$ water depth data and trapezoidal channel equations. Hydraulic radius is the ratio of the cross-sectional area of the flow at a point in an open channel to the wetted perimeter (Chin, 2000). Mean slope for the drainage ditches was 0.003875 .

\section{Manning's $n$ Ranges and Water Volume Estimation}

The Manning's coefficient in vegetative lined channels is a function of average velocity, hydraulic radius, and vegetation type (Bakry et al., 1992; Chin, 2000). Regression analysis revealed that variability in flow regime (hydraulic depth) and in vegetation density contributes significantly to variability in $n$ (Bakry et al., 1992). Manning's $n$ value is specific to a certain stream bed and thus is difficult to translate between stream/river/ditch systems. Manning's coefficients were estimated from the literature at 0.025 for the dormant season and 0.085 for the growing season (Bakry et al., 1992; Salama and Bakry, 1992; Sellin et al., 2003). However, a range of Manning's coefficients (0.010-0.040 dormant; 0.070-0.10 growing) were used for determining a buffer range of nutrient loads possibly leaving the agricultural landscape and to determine the sensitivity in changes of Manning's $n$ on nutrient load output $(\mathrm{kg}$ $\left.\mathrm{ha}^{-1}\right)$. Vegetation densities were similar between ditches.

Stormflow DIP and PP loads were determined as a product of the mean P (DIP or PP) concentration multiplied by the water volume per respective storm event. Ideally, temporal changes in total volume and discharge for storm events would be determined by installing and calibrating a V-flume/V-weir within each of the drainage ditches. However, the installation of hydrological monitoring devices was undesirable by the owner of the properties, and thus an alternate solution for the estimation of water flow was needed. Total water volume discharged per storm event was determined using a Natural Resources Conservation Service (NRCS) dimensionless unit hydrograph (Chin, 2000). This dimensionless hydrograph represents the average shape of a large number of unit storm hydrographs from natural catchments of different characteristics. The NRCS dimensionless unit hydrograph expresses the normalized runoff $\mathrm{Q} / \mathrm{Q}_{\mathrm{p}}$ as a function of the normalized time, $T / \mathrm{T}_{\mathrm{p}}$, where $\mathrm{Q}_{\mathrm{p}}$ is the peak runoff and $T_{p}$ is the time to peak of the hydrograph (Chin, 2000). The range of Manning's coefficients was also used to temper uncertainty and variability in nutrient loads within the hydrograph and discharge occurrences.

\section{Statistical Methods}

Spatial gradients of nutrient assimilation and loss within each drainage ditch were analyzed for baseflows using Pearson's correlations. Stormflow event gradients were analyzed by percentage reductions (max-minus outlet concentration) as a result of bellshaped nutrient concentration distributions along the drainage ditch. Data were divided into three classes: (i) yearly, ranging from June to May; (ii) dormant season, consisting of the months October to March; and (iii) growing season, consisting of the months April to September (Bengraine and Marhaba, 2003).

\section{Results}

\section{Hydrological Differences between 2004 and 2005}

Differences in hydrology between 2004 and 2005 (Table 1) resulted in marked differences in $\mathrm{P}$ concentrations and loads transported from the farms into the ditches and in the capacity of the ditch to mitigate P loads to receiving waters. Hydrologically, 2004 had a relatively dry growing season, small stages and discharges, no significant storm events occurring postfertilization, and a very wet dormant season with large, frequent, intense stormflow events (Table 1). Conversely, in 2005, precipitation patterns were similar between seasons, with significant storm events occurring postfertilization in the growing season and large intense storm events occurring over the dormant season.

\section{Baseflow: Source or Sink}

Source sink patterns for 2004 were not complex. The ditches acted as strong sinks for nutrient concentrations postfertilization (June-November 2004) and migrated to a weak sink with increased rainfall volume in the dormant season (Fig. 1; Table 2). At no point in 2004 did the ditches act as concentration sources for $\mathrm{P}$, as correlation coefficients remained negative with a spatial gradient of nutrient concentrations along the ditch. After fertilization in 2005, short, intense storm events resulted in excess DIP and PP moving into the ditches and thus acted as sources (July-September 2005) (Fig. 1; Table 2). From October 2005 to May 2006, the ditches became strong sinks for $\mathrm{P}$ and in time migrated to weak P sinks within the dormant season and early spring. More often than not ditches displayed sink capacities through 


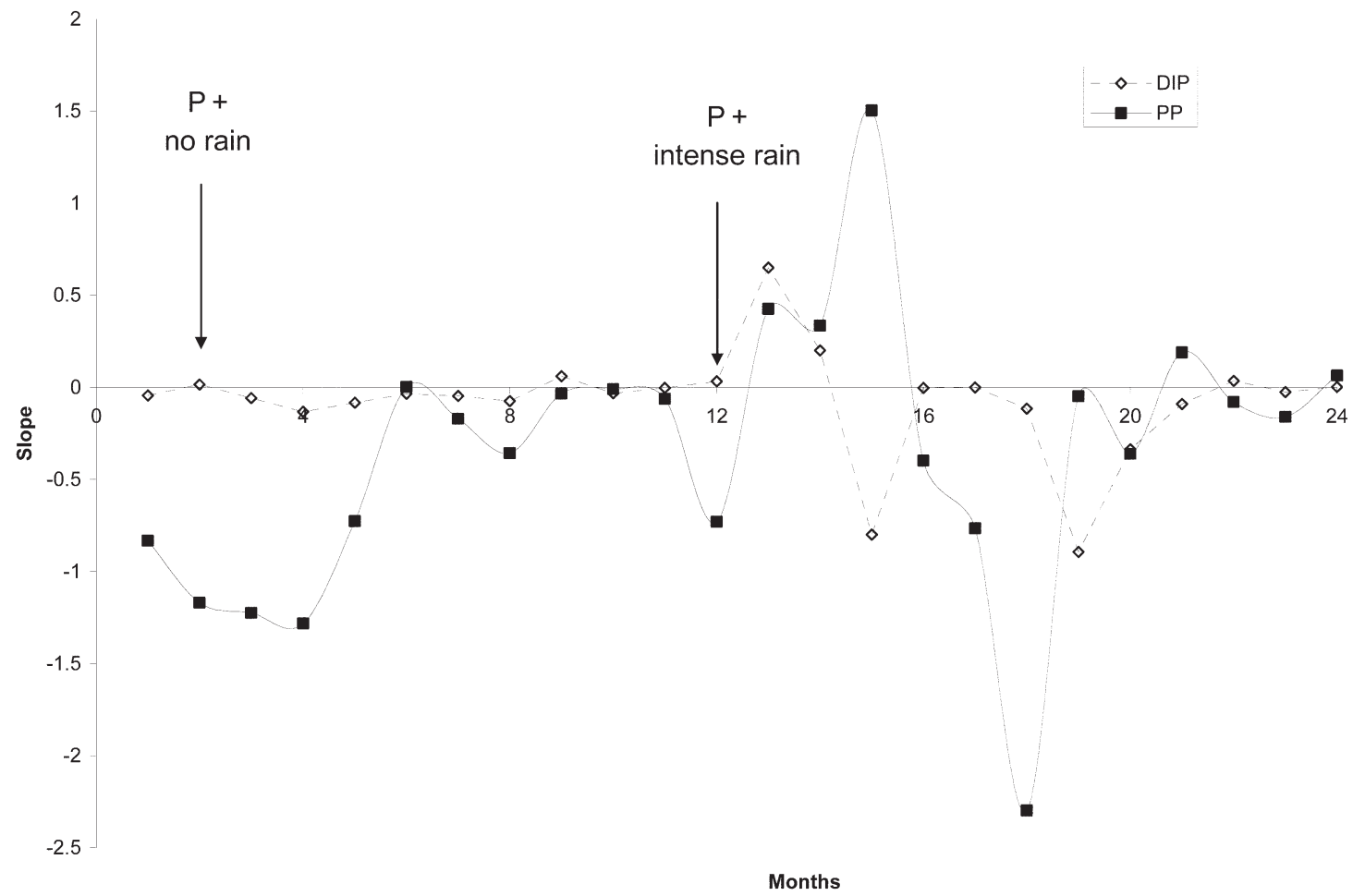

Fig. 1. Linear regression slopes for dissolved and particulate phosphorus nutrient reduction gradients over a 24-mo period (starting May 2004). In June 2004 (1 mo), fertilization and little rainfall occurred; in June 2005 (12-13 mo), fertilization and short, intense storm events occurred. Negative slopes indicate net sinks. Positive slopes indicate a net source

the dormant and growing season for PP and DIP and thus were significant sinks for baseflow P (Table 2).

\section{Stormflow: Source or Sink}

For 2004 and 2005, the ditches acted as sinks for PP during stormflows (Table 3). On average over the 2005 growing season (April-September), the ditch reduced PP concentrations in stormflow by $67.4 \%$. In the 2004 growing season, this average

Table 2. Correlation strengths of particulate phosphorus (PP) and dissolved inorganic phosphorus (DIP) against longitudinal distances $(\mathrm{m})$ of farm ditches.

\begin{tabular}{lccccc} 
& \multicolumn{2}{c}{ PP } & & \multicolumn{2}{c}{ DIP } \\
\cline { 2 - 3 } \cline { 5 - 6 } Month & $2004-05$ & $2005-06$ & & $2004-05$ & $2005-06$ \\
\hline May & $-0.873 \dagger$ & $\mathrm{N} / \mathrm{SS} \neq$ & & $\mathrm{N} / \mathrm{SS}$ & +0.751 \\
June & -0.638 & $\mathrm{~N} / \mathrm{SS}$ & & -0.903 & $\mathrm{~N} / \mathrm{SS}$ \\
July & -0.931 & +0.843 & & $\mathrm{~N} / \mathrm{SS}$ & +0.831 \\
Aug. & $-\S$ & +0.908 & & - & $\mathrm{N} / \mathrm{SS}$ \\
Sept. & $\mathrm{N} / \mathrm{SS}$ & $\mathrm{N} / \mathrm{SS}$ & & $\mathrm{N} / \mathrm{SS}$ & -0.824 \\
Oct. & - & $\mathrm{N} / \mathrm{SS}$ & & - & $\mathrm{N} / \mathrm{SS}$ \\
Nov. & $\mathrm{N} / \mathrm{SS}$ & -0.924 & & -0.813 & $\mathrm{~N} / \mathrm{SS}$ \\
Dec. & -0.799 & $\mathrm{~N} / \mathrm{SS}$ & & $\mathrm{N} / \mathrm{SS}$ & -0.883 \\
Jan. & -0.727 & -0.824 & & -0.830 & $\mathrm{~N} / \mathrm{SS}$ \\
Feb. & $\mathrm{N} / \mathrm{SS}$ & +0.560 & & $\mathrm{~N} / \mathrm{SS}$ & $\mathrm{N} / \mathrm{SS}$ \\
Mar. & -0.631 & $\mathrm{~N} / \mathrm{SS}$ & & -0.766 & $\mathrm{~N} / \mathrm{SS}$ \\
Apr. & $\mathrm{N} / \mathrm{SS}$ & $\mathrm{N} / \mathrm{SS}$ & & $\mathrm{N} / \mathrm{SS}$ & -0.809 \\
\hline
\end{tabular}

† A negative value indicates a sink (i.e., a net decrease in nutrient concentrations); a positive value indicates a source (i.e., a net increase in nutrient concentrations).

₹ N/SS indicates neither source nor sink. Biological significance of nutrient concentration was delineated as $r$ values $>25 \%$.

$\S$ - indicates ditch was dry. was reduced by two anomalous months (June and July), during which the ditch was a source of PP and reduced ditch retention to $4.3 \%$. Over the 2004 dormant season (October-March), the ditch reduced mean PP concentrations by 64.7 and $46.3 \%$ in 2005 (Table 3). Dissolved inorganic P had interannual variation in its contribution to downstream environments (December 2004: -27.5\%; December 2005: +6\%) (Table 3). On average, the ditches reduced DIP concentrations in the growing

Table 3. Stormflow retention percentages for particulate phosphorus (PP) and dissolved inorganic phosphorus (DIP) longitudinally (m) along farm ditches.

\begin{tabular}{|c|c|c|c|c|}
\hline \multirow[b]{2}{*}{ Month } & \multicolumn{2}{|c|}{ PP } & \multicolumn{2}{|c|}{ DIP } \\
\hline & 2004-05 & 2005-06 & 2004-05 & 2005-06 \\
\hline & & 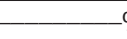 & 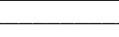 & 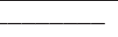 \\
\hline Jan. & $13+$ & 8.5 & 74 & 74 \\
\hline Feb. & 90.5 & 22.5 & 85.5 & 43.5 \\
\hline Mar. & NS‡ & 76 & NS & 63 \\
\hline Apr. & NS & 61 & NS & 47.5 \\
\hline May & NS & 72.5 & NS & 70.5 \\
\hline June & -61 & 92 & 90 & 47 \\
\hline July & -39 & 35 & -53.5 & 56 \\
\hline Aug. & 41 & NS & 82 & NS \\
\hline Sept. & 83 & 89 & 32 & 81.5 \\
\hline Oct. & 58.5 & NS & 80 & NS \\
\hline Nov. & 88.5 & 63 & 78 & 7.5 \\
\hline Dec. & 72 & 61 & -27.5 & 6 \\
\hline
\end{tabular}

$\uparrow$ A positive percentage indicates a reduction between maximum effluent and outflow nutrient concentration. A negative percentage indicates an increase in concentration.

‡ NS, no storms occurred. 
Table 4. Maximum farm effluent and outflow phosphorus loads for two drainage ditches during stormflows for 2004 and 2005. Loads based on Natural Resources Conservation Service dimensionless storm hydrographs and Manning's $n$ coefficients of 0.025 (Dormant) and 0.085 (Growing).

\begin{tabular}{|c|c|c|c|c|c|c|}
\hline \multirow[b]{2}{*}{ Year } & & \multirow{2}{*}{$\begin{array}{c}\text { Total water } \\
\text { volume }\end{array}$} & \multicolumn{2}{|c|}{ Maximum $P$ effluent load $†$} & \multicolumn{2}{|c|}{ Outflow P load } \\
\hline & & & Mean DIP per storm event & Mean PP per storm event & Mean DIP per storm event & Mean PP per storm event \\
\hline & & $\mathrm{L}$ & & 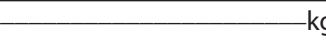 & 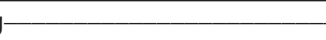 & \\
\hline \multicolumn{7}{|l|}{ 2004-05 } \\
\hline \multirow[t]{2}{*}{ Growing } & Farm 1 & $108,244.2$ & $0.025 \pm 0.02$ & $0.084 \pm 0.05$ & $0.013 \pm 0.009$ & $0.051 \pm 0.04$ \\
\hline & Farm 2 & $183,383.7$ & $0.014 \pm 0.008$ & $0.049 \pm 0.03$ & $0.004 \pm 0.002$ & $0.019 \pm 0.02$ \\
\hline \multirow[t]{2}{*}{ Dormant } & Farm 1 & $2,159,206$ & $0.158 \pm 0.082$ & $1.095 \pm 0.67$ & $0.07 \pm 0.043$ & $0.73 \pm 0.46$ \\
\hline & Farm 2 & $1,379,103$ & $0.532 \pm 0.49$ & $1.281 \pm 0.73$ & $0.280 \pm 0.265$ & $0.89 \pm 0.54$ \\
\hline \multicolumn{7}{|l|}{$2005-06$} \\
\hline \multirow[t]{2}{*}{ Growing } & Farm 1 & $420,080.5$ & $0.289 \pm 0.21$ & $0.325 \pm 0.25$ & $0.150 \pm 0.09$ & $0.09 \pm 0.057$ \\
\hline & Farm 2 & $648,233.5$ & $0.464 \pm 0.28$ & $0.17 \pm 0.12$ & $0.247 \pm 0.15$ & $0.06 \pm 0.037$ \\
\hline \multirow[t]{2}{*}{ Dormant } & Farm 1 & $790,132.9$ & $0.255 \pm 0.10$ & $0.326 \pm 0.16$ & $0.098 \pm 0.036$ & $0.195 \pm 0.13$ \\
\hline & Farm 2 & $1,054,238$ & $0.405 \pm 0.24$ & $0.54 \pm 0.30$ & $0.164 \pm 0.07$ & $0.290 \pm 0.20$ \\
\hline
\end{tabular}

† DIP, dissolved inorganic phosphorus; P, phosphorus; PP, particulate phosphorus.

season by $60.3 \%$ in 2004 and $62 \%$ in 2005 and in the dormant season by $55 \%$ in 2004 and $38.6 \%$ in 2005 .

\section{Drainage Ditch Load Mitigation}

There were no significant statistical differences in DIP load reduction for stormflows (Tables 4 and 5) for 2004 (49.40 $\pm 5.72 \%)$ and $2005(38.02 \pm 7.42 \%)\left(t_{44}=1.232 ; p=0.224\right)$. Differences in PP reduction were weakly significant between 2004 (38.07 \pm $6.35)$ and $2005(50.68 \pm 5.35)\left(t_{42}=-1.898 ; p=0.06\right)$. Increased water discharges (Table 1 ) and correlated water volumes (Table 4) in the 2004 dormant season subsequently reduced the capacity of PP reduction within the ditch to $33.07 \%( \pm 7.08)$. However, in the 2005 dormant season, when water volumes were less, the PP reduction increased to $52.19 \%( \pm 5.25)$ (Table 5). A higher water volume in 2004 resulted in a larger TIP load $(22.505 \mathrm{~kg})$ than $2005(18.16 \mathrm{~kg})$. Overall, the total storm load lost from the farms over the $2 \mathrm{yr}$ was $40.66 \mathrm{~kg}\left(3.31 \mathrm{~kg} \mathrm{ha}^{-1} \mathrm{yr}^{-1}\right)$. This maximum effluent loss from the farm was $5.5 \%$ of the initial fertilizer application. The ditches retained $47 \%$ of TIP from the maximum effluent loss, reducing this initial loss to $2.41 \%$ of the initial application with $1.43 \mathrm{~kg} \mathrm{ha}^{-1} \mathrm{yr}^{-1}$ reaching receiving waters.

\section{Ranges in Manning's $n$}

Changes in Manning's $n$ within the Manning's equation results in either increases or decreases in flow and subsequently discharge volume in the NRCS unit hydrograph. For the growing season, a Manning's $n$ range from 0.07 to 0.1 produced a maximum effluent load range for TIP (DIP + PP) of 1.31 to $0.838 \mathrm{~kg} \mathrm{ha}^{-1}$ for 2004 and 9.15 to $6.3 \mathrm{~kg} \mathrm{ha}^{-1}$ for 2005. The largest range of loads occurred for maximum TIP loads over the dormant season in 2004 $\left(54.12-13.3 \mathrm{~kg} \mathrm{ha}^{-1}\right)$. The smallest ranges of loads occurred for growing season outflow TIP in 2004 $\left(0.791-0.42 \mathrm{~kg} \mathrm{ha}^{-1}\right)$. Dissolved inorganic P and PP maximum and outflow loads for both seasons over 2004 and 2005 were significantly sensitive to changes in Manning's $n\left(r^{2}>0.85\right)$. However, no matter the range $\left(\mathrm{kg} \mathrm{ha}^{-1}\right)$ of maximum effluent or outflow loads, both loads were equally affected by changes in discharges and discharge volumes, thus negating any influences on changes in reductions percentages within the drainage ditch.

\section{Discussion}

North Mississippi agricultural drainage ditches were mitigation tools for P reduction. Over the course of the study, drainage ditches reduced TIP storm loads by approximately $45 \%$ for both years. Differences in reduction potential between P species can be explained by differences in the hydrology between years. Increased water volumes over the dormant season of 2004 reduced the ditches' capacity to reduce PP by approximately 13\%. Discharge volumes had little effect on the ability of the ditch to mitigate DIP loads (except postfertilization in the growing season of 2005) because DIP was a P species that was quickly adsorbed to sediment and assimilated by crops and ditch vegetation over the growing season (Kröger et al., 2007). Total inorganic P load from the farm totaled $3.13 \mathrm{~kg} \mathrm{ha}^{-1} \mathrm{yr}^{-1}$, nearly double that reported by Klaine et al. (1988). Barlow et al. (2003) reported a significant decrease in $\mathrm{P}$ concentrations in drainage water within farm drains (160 m long) where surface drains could retain 6 to $8 \mathrm{~kg} \mathrm{P} \mathrm{yr}^{-1}$,

Table 5. Mean percentage load reduction of dissolved inorganic phosphorus (DIP) and particulate phosphorus (PP) in agricultural drainage ditches between June 2004 and June 2006.

\begin{tabular}{llcc} 
Year & & $\begin{array}{c}\text { Mean reduction } \\
\text { in DIP load }\end{array}$ & $\begin{array}{c}\text { Mean reduction } \\
\text { in PP load }\end{array}$ \\
\hline 2004-05 & & \multicolumn{2}{c}{$\% \pm$ SE } \\
\cline { 2 - 3 } Growing $(n=0.085)$ & Farm 1 & $44.29 \pm 16.5$ & $49.67 \pm 13.5$ \\
& Farm 2 & $36.13 \pm 20.9$ & $41.06 \pm 21.8$ \\
& seasonal cumulative avg. & $40.6 \pm 12.3$ & $45.85 \pm 11.52$ \\
Dormant $(n=0.025)$ & Farm 1 & $56.4 \pm 7.14$ & $25.19 \pm 12.22$ \\
& Farm 2 & $54.30 \pm 10.23$ & $40.96 \pm 8.93$ \\
& seasonal cumulative avg. & $55.5 \pm 5.71$ & $33.07 \pm 7.08$ \\
2005-06 & annual avg. & $49.40 \pm 5.72$ & $38.07 \pm 6.35$ \\
Growing $(n=0.085)$ & Farm 1 & $22.47 \pm 16.57$ & $46.5 \pm 17.34$ \\
& Farm 2 & $30.5 \pm 10.03$ & $50.49 \pm 11.27$ \\
& seasonal cumulative avg. & $26.45 \pm 9.31$ & $48.32 \pm 11.04$ \\
Dormant $(n=0.025)$ & Farm 1 & $53.7 \pm 5.19$ & $51.33 \pm 9.64$ \\
& Farm 2 & $31.29 \pm 18.6$ & $53.05 \pm 5.14$ \\
& seasonal cumulative avg. & $42.49 \pm 9.7$ & $52.19 \pm 5.25$ \\
& annual avg. & $38.02 \pm 7.42$ & $50.68 \pm 5.35$ \\
\hline
\end{tabular}


which represented a $14 \%$ reduction in P export. Particulate P loads exported from row-crop agriculture in northern Mississippi were above average (Grant et al., 1996; Fraser et al., 1999), whereas DIP loads were very similar to $0.38 \mathrm{~kg} \mathrm{ha}^{-1}$ monitored in small agricultural watersheds in Georgia (Smith et al., 1978) and $0.22 \mathrm{~kg} \mathrm{ha}^{-1}$ (range, 0.04-0.53) in Germany (Chambers et al., 2006). Kovacic et al. (2000) commented that overall removal of P for constructed wetlands was only about $2 \%$ of an initial effluent load during a 3-yr study, with hydrological variations driving highly variable results within wetlands and between years.

Best management practices are implemented to improve crop yields and increase economic sustainability while significantly decreasing loss of nonpoint source pollutants such as fertilizers. The cotton farms reported on were farmed in no-till, a management practice meant to reduce the amount of fertilizer loss through leaching and macropore flow and to reduce sediment load in surface flows. No-till, when compared with other tillage methods, generally produces more surface runoff and volumes and requires less time from precipitation to runoff (Daverede et al., 2003). This suggests another reason why $\mathrm{P}$ loads, specifically in northern Mississippi where there is a wet dormant season, were variable between seasons as a result of changes in runoff volume. Studies show spatial and temporal variation in concentrations and loads of P in surface runoff (e.g., Indian river lagoon [He et al., 2003], Finnish rivers [Raike et al., 2003], and west Tennessee [Klaine et al., 1988]). Surface runoff and stormflows in this study resulted in $6 \%$ of the annual applied fertilizer to be transported in stormflows from the farm. Drainage ditches intercepting variable stormflow loads tended to be seasonally variable in the ability to mitigate specific P loads. However, apart from Barlow et al. (2003), few studies have examined the changes in effluent $\mathrm{P}$ load between exportation off the agricultural landscape and entering receiving waters in any capacity, let alone between seasons. The agricultural drainage ditches overall reduced an initial effluent load applied, to $2.4 \%$ actually reaching downstream receiving waters. Seasonal fluxes in hydrology and fertilization influence $P$ dynamics of water and sediment, with evidence for the accumulation of $\mathrm{P}$ in low flow periods (growing season) and the scouring of sediments in high flow (dormant season) (Raisin and Mitchell, 1995; House and Denison, 1998).

Caution must be used when interpreting percentage lost from annual fertilizer applications. Applied P has the tendency to accumulate in the soils; thus, P moving in surface runoff could potentially be annual applications of $\mathrm{P}$ applied years previously. The lack of adequate instrumentation, through lack of land ownership (private farm), to gauge flow dynamics and discharges results in either an over- or underestimation of effluent P loads. However, similar findings of P loads (Smith et al., 1978; Klaine et al., 1988; Chambers et al., 2006), surface runoff concentrations (Sharpley, 1980; Sharpley et al., 1992; He et al., 2003), and potential reduction percentages in agricultural drainage ditches (Barlow et al., 2003) suggest that the use of a dimensionless NRCS hydrograph in conjunction with a conservative Manning's $n$ estimation produces very comparable load ranges. Prolific growth of hydrophytic emergent and submerged species and subsequent senescence in the dormant season results in changes to Manning's $n$ throughout the year. A distinct classification of two endpoints of Manning's $n$ ( 0.025 and
$0.085)$ is necessary to determine minimum and maximum load ranges, while ranges in $n$ would suggest changes in load through transition periods between growth and senescence.

Improvements to drainage ditch reduction capacity could be made by modifying the function of the drainage ditch and installing controlled drainage structures. Improving hydraulic retention time and reducing drainage with low-grade weirs can potentially increase sedimentation rates and water residence time associated with high flows in winter/dormant/ rainy season while increasing sediment DIP adsorption postfertilization without causing farm flooding and crop senescence through soil saturation throughout the growing season.

\section{Acknowledgments}

Financial support was received through the co-operative agreement from the USDA-ARS No. 58-6408-1-095 to the University of Mississippi and the Ralph Powe Award through the UMFS. The authors thank an anonymous farmer for help; Joe Huggins and Mackie Riddle at the NRCS, Oxford, MS; and Landon Lee, Toyal Flemons, and Lisa Williams for sample preparation and analysis.

\section{References}

American Public Health Association. 1998. Standard methods for the examination of water and wastewater. 20th ed. American Public Health Association, Washington, DC.

Bakry, M.F., T.K. Gates, and A.F. Khatab. 1992. Field-measured hydraulic resistance characteristics in vegetation-infested canals. J. Irrig. Drain. Eng. 118:256-274.

Barlow, K., D. Nash, H. Turral, and R. Grayson. 2003. Phosphorus uptake and release in surface drains. Agric. Water Manage. 63:109-123.

Bengraine, K., and T.F. Marhaba. 2003. Using principal components analysis to monitor spatial and temporal changes in water quality. J. Hazard. Mater. B100:179-195.

Broberg, O., and G. Persson. 1988. Particulate and dissolved phosphorus forms in freshwater: Composition and analysis. Hydrobiologia 170:61-90.

Chambers, P.A., R. Meissner, F.J. Wrona, H. Rupp, H. Guhr, J. Seeger, J.M. Culp, and R.B. Brua. 2006. Changes in nutrient loading in an agricultural watershed and its effects on water quality and stream biota. Hydrobiologia 556:399-415.

Chin, D.A. 2000. Water resources engineering. Prentice Hall, New Jersey.

Daverede, I.C., A.N. Kravchenko, R.G. Hoeft, E.D. Nafziger, D.G. Bullock, J.J. Warren, and L.C. Gonzini. 2003. Phosphorus runoff: Effect of tillage and soil phosphorus levels. J. Environ. Qual. 32:1436-1444.

Dils, R.M., and A.L. Heathwaite. 1999. The controversial role of tile drainage in phosphorus export from agricultural land. Water Sci. Technol. 39:55-61.

Fausey, N.R., L.C. Brown, H.W. Belcher, and R.S. Kanwar. 1995. Drainage and water quality in Great Lakes and Cornbelt states. J. Irrig. Drain. Eng. 121:283-288.

Fraser, A.I., T.R. Harrod, and P.M. Haygarth. 1999. The effect of rainfall intensity on soil erosion and particulate phosphorus transfer from arable soils. Water Sci. Technol. 12:41-45.

Grant, R., A. Laubel, B. Kronvang, H.E. Andersen, L.M. Svendsen, and A. Fuglsang. 1996. Loss of dissolved and particulate phosphorus from arable catchments by subsurface drainage. Water Res. 30:2633-2642.

Haygarth, P.M., A.L. Heathwaite, S.C. Jarvis, and T.R. Harrod. 2000. Hydrological factors for phosphorus transfer from agricultural soils. Adv. Agron. 69:153-178.

He, Z.L., M.K. Zhang, D.V. Calvert, P.J. Stoffela, and Y.C. Li. 2003. Loading of phosphorus in surface water runoff in relation to management practices and soil properties. Proc. Soil Crop Sci. Soc. Fla. 62:12-20.

Heathwaite, A.L., and R.M. Dils. 2000. Characterizing phosphorus loss in surface and subsurface hydrological pathways. Sci. Total Environ. 251-252:523-538. 
House, W.A., and F.H. Denison. 1998. Phosphorus dynamics in a lowland river. Water Res. 32:1819-1830.

House, W.A., F.H. Denison, and P.D. Armitage. 1995. Comparison of the uptake of inorganic phosphorus to a suspended and stream bedsediment. Water Res. 29:767-779.

Jolankai, G., and W. Rast. 1999. The hydrologic cycle and factors affecting the generation, transport and transformation of non-point source pollutants. p. 41-72. In J.A. Thornton et al. (ed.) Assessment and control of nonpoint source pollution of aquatic ecosystems: A practical approach. UNESCO \& Parthenon Publishing Group, New York.

Klaine, S.J., M.L. Hinman, D.A. Winkelmann, J.R. Martin, K.R. Sauser, and L.W. Moore. 1988. Characterization of agricultural nonpoint pollution: Nutrient loss and erosion in a west Tennessee watershed. Environ. Toxicol. Chem. 7:601-607.

Kovacic, D.A., M.B. David, L.E. Gentry, K.M. Starks, and R.A. Cooke. 2000. Effectiveness of constructed wetlands in reducing nitrogen and phosphorus export from agricultural tile drainage. J. Environ. Qual. 29:1262-1274.

Kröger, R., M.M. Holland, M.T. Moore, and C.M. Cooper. 2007. Plant senescence: A mechanism for nutrient release in temperate agricultural wetlands. Environ. Pollut. 146:114-119.

Moore, M.T., Jr., J.H. Rodgers, C.M. Cooper, and S. Smith Jr. 2000 Constructed wetlands for mitigation of atrazine-associated agricultural runoff. Environ. Pollut. 110:393-399.

Morris, W.M. 1981. Soil survey of Lafayette County, Mississippi. USDA Soil Conservation Service and Forest Service, Washington, DC.

Murphy, R., and J.P. Riley. 1962. A modified single solution method for the determination of phosphate in natural waters. Anal. Chim. Acta 27:31-36.

Rabalais, N.N., G.A. Turner, Q. Dortch, W.J. Wiseman, Jr., and B.K.S. Gupta. 1996. Nutrient changes in the Mississippi River and system responses on the adjacent continental shelf. Estuaries 19:386-407.
Raike, A., O.P. Pietilainen, S. Rekolainen, P. Kauppila, H. Pitkanen, J. Niemi, A. Raateland, and J. Vuorenmaa. 2003. Trends of phosphorus, nitrogen and chlorophyll a concentrations in Finnish rivers in 19752000. Sci. Total Environ. 310:47-59.

Raisin, G.W., and D.S. Mitchell. 1995. The use of wetlands for the control of non-point source pollution. Water Sci. Technol. 32:177-186.

Salama, M.M., and M.F. Bakry. 1992. Design of earthen vegetated open channels. Water Resour. Manage. 6:149-159.

Sellin, R.H.J., T.B. Bryant, and J.H. Loveless. 2003. An improved method for roughening floodplains on physical river models. J. Hydraul. Res. 41:3-14.

Sharpley, A.N. 1980. The effect of storm interval on the transport of soluble phosphorus in runoff. J. Environ. Qual. 9:575-578.

Sharpley, A.N., S.C. Chapra, R. Wedepohl, J.T. Sims, T.C. Daniel, and K.R. Reddy. 1994. Managing agricultural phosphorus for protection of surface waters: Issues and options. J. Environ. Qual. 23:437-451.

Sharpley, A.N., T.C. Daniel, J.T. Sims, and D.H. Pote. 1996. Determining environmentally sound soil phosphorus levels. J. Soil Water Conserv. 51:160-166.

Sharpley, A.N., S.J. Smith, O.R. Jones, W.A. Berg, and G.A. Coleman. 1992. The transport of bioavailable phosphorus in agricultural run-off. J. Environ. Qual. 21:30-35.

Smith, C.N., R.A. Leonard, G.W. Langdale, and G.W. Bailey. 1978. Transportation of agricultural chemicals from small upland Piedmont watersheds. EPA-600/3-78-056. USEPA, Athens, GA.

Turner, R.E., and N.N. Rabalais. 2003. Linking landscape and water quality in the Mississippi River Basin for 200 years. Bioscience 53:563-572.

Wright, R.B., B.G. Lockaby, and M.R. Walbridge. 2001. Phosphorus availability in an artificially flooded Southeastern Floodplain Forest soil. Soil Sci. Soc. Am. J. 65:1293-1302. 